\title{
An empirical study on general insurance agents' performance in Sri Lankan insurance industry
}

\author{
Muthusamy, V \\ Department of Accountancy and Finance, \\ Faculty of Management Studies, \\ Sabaragamuwa University of Sri Lanka
}

\begin{abstract}
The confrontational thoughts and poor risk management knowledge has been lead to a complex competitive environment Sri Lankan general insurers. The general public trust on insurance industry became a major problem for the development of the general insurance industry. The insurance regulator of the insurance industry evidenced through the statistical data that general insurance industry has not developing in a desirable growth rate. The penetration has been extremely low for many years. The insurance companies' existence depends on their competent human resources, especially the agents. Thus, the general insurers attempt to concentrate on sales agents performances to improve the company sales to capture a significant market share. Therefore, this study pertained to explore the existing relationship between sales persons skills and agents performance in general insurance industry in Sri Lanka. The study was utilized quantitative method by using questionnaires to randomly selected 331 insurance advisors from general insurance industry. The study selected selling skill dimensions (Interpersonal Skills, Salesmanship Skills, Technical Skills, Marketing Skills) as dependent variables and salesperson sales performance as independent variables. The study confirmed interpersonal skill most influencing factor on sales person performance.
\end{abstract}

Key Words: Insurance, Selling skill, Sales performance, Relationship

\section{Introduction}

Conventional general insurers are experiencing a dismal condition in Sri Lanka. The most influencing reasons for the disruption of this sector extreme weather condition, increased administrative cost due to regulatory changes, decelerate vehicle sales, rupee depreciation and the customers' bad impression on insurance sector.
Moreover, this industry ranked as a low profit attractive industry because of following reasons: Firstly, the general insurance industry has driven by the motor as well as health insurance policy products which are loss making classes. These insurance policy lines contain more than $50 \%$ of the general insurance industry portfolio (IBSL, 2015). This is the core 
problem of the industry which has been lagging on their growth. The loss making lines depressed the development of the sector because of the high claim ratio and combined ratios on the other hand lowest GWP earning from motor and health insurance. The second important reason of general insurance industry is intense bad competition. The bad competitive environment blurred the underwriters discipline and triggered the underwriters to undercut the premium amounts to capture the market share. Furthermore, the regulatory body of Insurance industry of Sri Lanka revealed that the general insurance industry penetration level too low for a longer period which emphasize the general insurers continuously struggling to increase their market share (Weeralingam and Illangasekara, 2011), in 2015 the penetration level was recorded only $0.66 \%$ (IBSL,2015). This is very low against an average in the Asian region (IBSL, 2015) but in other way round it upheld that the general insurance industry has a considerable unexploited market for their further expansion in Sri Lanka. Therefore, the general insurers focused attract profitable customer segments and build strong and close relationship with them to increase the company profit level. The long lasting customer relationship will ensure the survival of the general insurance companies' though it is suppressed by the complex problems (Muthusamy \& Fernando, 2016). With respect to the dynamic environment the general insurers focus on their efforts on company sales. The general insurers' sales highly depend on direct sales channel therefore, sales person playing a vital role to maximize the market contribution of the company (Farhang and Hasely, 2013).

Sales persons role in an insurance company is important not only in insurance industry but also telecommunication, banking (Jarrar and Neely, 2002), engineering, chemical industry (Schmitz, 2014), financial services, insurance, health care, accounting, airlines, and retailing” ( $\mathrm{Li}$, Sun and Montgomery, 2011). Previous empirical researches evidenced that most important commonalities also differ according to the sales person nature and the industry (Johlke, 2006). There are numerous factors affecting the sales performance and the management attempt to improve the company sales, for that, the management of the company headhunt skilled sales persons to maximize their sales outcomes. Therefore, it is important to have an understanding on most needed skills for sales persons. The research aimed to ripe for extensive understanding on general insurance industry sales person skills and how it contributes to their sales performance.

\section{Literature review and hypothesis}

In service industry customers are the most important asset. Service organizations are trying to adapt strategies to retain their customers (Salazar, 2010). "Customer relationship management, which consists of acquiring, retaining and growing or expanding customer relationships with a 
firm, is an important endeavor for modern service organizations" (Gunes et al. 2010, p.3). Cross selling is a one of the main tool of customer relationship management to retain the existing customers in an organization (Kamakura, Ramaswami and Srivastava 1991; Kamakura et al. 2002; Schmits, Lee and Lilien, 2014; Gunes et al. 2010).

Alberts et al. (2006) says organizations are facing difficulty for building a strong customer relationship between company and the customers. Globalization offered various options to the customers buying preferences therefore the customers' massive choices leads to churn with other products.

Insurance is a risk transferring mechanism" insurer offers a chance for transfer the uncertain loss to certain loss in return of premium payment (Holyoake and Weipers, 2002). Through insurance insured receive financial compensation in an event from insured in return of consideration. Insurance contract is a legal engagement between insured and insurer. Insurance has defined "A contract whereby one person called the insurer undertakes in return for an agreed price called premium to pay to another person called, insured a sum of money on the happening of a specified event (Rahmanjee, 2007,p.5). Insurance dived into two classes: life insurance and general insurance.

Life insurance is a long term insurance which named as long term assurance. It is a contract of a human life related to death or uncertain events. The contact value is based on the human life value. The life insurance split into following sub classes: life insurance, linked long term, annuities, and contracts for the granting of disability and multiple indemnities, accident and sickness benefits, permanent health, capital redemption contracts and pension policies (Rahmanjee, 2007).

General insurance defined as "Any insurance which does not fall within the scope of long- term insurance may be considered to fall within the scope of general insurance" (Thangakone, 2001, p.41). general insurance consist of four classes: marine, aviation and transport insurance, fire insurance, motor vehicle insurance, employee liability insurance and miscellaneous insurance.

IBSL (2015) reveals in general insurance industry customer attraction and retention are difficult and challenging task than other industry moreover, In customer churn rate in high because general insurance products are mostly featured per annum policies (Weitz and Bradford, 1999). To identify and retain the right customer and prospect the salesperson skills are highly needed for this industry.

\subsection{Interpersonal skills and salesmanship} Skills

Most of the researches revealed that strong interpersonal skills lead to great sales targets (Farhang and Hasely, 2013). Interpersonal skills contain several dimensions (Rentz et 
al. 2002). According to Castleberry \& Shepherd (1993) listening skill has a vital importance to build a good agents' with a great outcome. In other words, it can be explained that both verbal and nonverbal fluency in communication. Churchil et al. (1985) states from the Meta analysis, the micro skills have a great impact on sales performance and the interpersonal skill one of the most important skill among them. Another good predictor of the sales performance is salesmanship skills (Basir and Berhad, 2010 p.54) revealed "The dimensions of salesmanship skills can be generally categorized into five subcategories that are: adaptability, consultative selling, negotiation and questioning, and salesperson cues and communication style skills". Johlke (2006) emphasized salesmanship skills help as the cornerstone for the salesperson from the beginning to end of the sales process and also in management perspective salesman skills viewed as the success factors of the sales performance.

The literature suggests following first and second hypothesis:

H1: There is a significant relationship between interpersonal skills and salesperson performance.

H2: There is a significant relationship between salesmanship skills and salesperson performance.

\subsection{Technical skill and marketing skills}

The technical skill considers another important factor which is sales person's product or service portfolio adaption. Sales person lack of knowledge in product portfolio will reflect bad effect on selling (Schmits, Lee and Lilien, 2014). The sales person must have enough knowledge to provide information regarding the product specifications, terms and conditions (Basir, Ahmad \& Kitchen, 2010). Marketing skills referred as problem solving skills (Weitz \& Bradfor, 1999) and also it referred as sales person knowledge on which market and environment him/her working for. High marketing skilled salesperson can render any type of information in a clear manner as per the customer requirements which heightened the sales of a products or services (Basir, Ahmad \& Kitchen, 2010). Thus, the third and fourth hypothesis were:

H3: There is a significant relationship between technical skills and salesperson performance.

H4: There is a significant relationship between marketing skills and salesperson performance.

\subsection{Sales performances}

Every organization aligned their sales units according to their marketing objectives. Sales unit refers a territory which belongs to an individual or a team or an organization (Darmon et al., 2013). Long run cross selling performance can be measure in a cost effective way such as sales units, sales volume and market share and profits. The sales performance is effects by following key factors organization culture, pattern, 
management and leadership (Cited in Harris, 2001). "Sales performance measured by sales volume, dollar sales, managerial evaluation or self-report measure of self-effectiveness" (Krishnan et al.2002, p.285).

Sales performance highly depends on sales representative's hard work (Brown and Peterson, 1994) and motivation will improve their work effort. In sales person perspective their performances rely on role clarity goal orientation, experience, selling behaviour adaption which generate high positive to perform well (Brown and Peterson, 1994; Terho et al., 2013). Sales person effective selling performances will generate loyal customer segment as well as rich sales profit (Schmitz et al., 2014). Rich quality and valued relationships will increase sales performance of the company and achieve profitability targets (Kamkura et al. 2002). Many scholars stated advancements in competition pressed organization to adapt technology to improve their sales, which supports to quick and quality customer service and it saves time to concern extra work on their job (Demirdjan, 1984; Rapp et al., 2008).Kazen et al (2013) study reveals a new factor; in insurance company sales representatives charming personality will be generate higher sales performance via strong motivation. Scholars revealed to improve sales not only sales person but also organization should influence the sales performance (Rapp et al., 2008; Roman and Lacobucci, 2010). Product portfolio and sales adaption is an utmost to improve sales performance both managers and sales people. Darmon et al. 2013) observed many companies marketing targets are not achieving because of management and working force commitment, ineffective management judgment and decisions, unsatisfied employees.

In general insurance sales persons are playing important role sales persons are pushing to generate review in the organization (ErastusYamoah, 2013). Sales persons are the people who represent the company products and services. People attracted to the products via sales representatives. Especially in insurance organization highly depend on sales representatives. The customer in insurance attracted by various sales representatives: "brokers agents and banking repres entatives" (Kavoosi et al., 2014, p.75).

Many studies have defined degree of sales performance directed by various sales skills not only the skills but also on sales person's hard work (Brown and Peterson, 1994). The dependent variable of this study and research have defined that sales persons skill will be the important factor which effects sales performance and sales persons personality (Kazen,2013) similarly key performance measures are skills, adaption of product portfolio and selling skills of sales person. Weitz et al. (1986) says sales performance relies on understanding of customer needs. Hence, the study concern on sales performance and it increase the profitability goals and it will result to capture significant market share (Schemitz, Lee and Lilian, 2014). 


\section{Research Methodology}

Study was conducted using quantitative research method. The quantitative data focused on discovering facts regarding social phenomena (Sekaran, 2010). The study was limited to the Sri Lankan contest. This study used primary data which collected by using a structured questionnaire. The study contains the Sample using as 331 general insurance agents from five general insurance companies. The five leading general insurance companies are ranked and selected according to the highest five market share from the general insurance industry. The sample selection was based on simple random sampling method which represents the characteristics of the population and the objectives of the study. The quantitative data nalysed in this study using descriptive and statistical techniques such as descriptive analysis (mean, median, and standard deviation) and correlation between variables tested more over the regression analysis conducted by utilizing SPSS software 16.0

\section{Results and discussion}

This section will present the findings of the study generated through the data analysis. According to Sekaran (2010) the internal consistency of the instruments checked using the Cronbach's coefficient alpha. The value indicate above (0.7) rule of thumb.

\subsection{Sampling adequacy test and reliability test}

$\mathrm{KMO}$ is a test which measure the adequacy of the index in which examines the factor appropriateness. YorMalhotra (2006) study says that higher result of the KMO test results are 0.5 to 0.1 appropriate on the other hand if it is too small close to zero then it indicate the inappropriateness. The appropriateness reflects the generalizability of the study population as well as sample. Reliability checked by using Cronbach's alpha value method. The method sates that the Alpha values results more than or close to 0.70 It indicate more reliability of questions are appropriate to measure. Table 1 shows the study of all the dimensions in independent and dependent reliability in accepted level.

Table 1 Reliability Statistics

\begin{tabular}{ll}
\hline Cronbach's Alpha & N of Items \\
\hline .755 & 4 \\
\hline
\end{tabular}

Source: (Survey data, 2017)

KMO is a test reveals the factor appropriateness. The value of 0.827 reveals generalizability of the sample to the population.

\subsection{Bivariate Analysis}

According to projected results highest positive association exist between interp ersonal skills and sales performance. The correlation between interpersonal skills and sales performance is $\mathrm{r}=0.677$ and $\mathrm{P}=0.000$ at $95 \%$ significance level. Association between salesmanship skill, marketing skills and sales performance of the company has moderate positive correlation and significance at 95\% level $(r=0.550$, 
$\mathrm{P}=0.000)$ and $(\mathrm{r}=0.499, \quad \mathrm{P}=0.000)$

respectively. There is a weak positive association indicates between technical skills and sales performance since $\mathrm{r}=0.299$ and $\mathrm{P}=$ 0.000 .

According to above justification researcher developed regression equation as follows:

$\mathrm{Y}($ sales performance $)=0.554+0.515$

(Interpersonal Skills) +0.147 (Marketing Skills) +0.184 (Salesmanship Skills).

\subsection{Multiple Regression Analysis}

The final model Table 2 shows that the researcher identified four sales skills dimensions having $71 \%$ of relationship with sales performance and the remaining 29\% covered by other factors. The model contains a positive relationship between independent and dependent variables. The $\mathrm{R}^{2}$ indicates three independent variables are positively impact cross selling performance by $50.4 \%$.

Table 2: Model Summary

\begin{tabular}{|c|c|c|c|c|c|}
\hline Model & $\mathrm{R}$ & $\begin{array}{c}\mathrm{R} \\
\text { Square }\end{array}$ & $\begin{array}{l}\text { Adjusted R } \\
\text { Square }\end{array}$ & $\begin{array}{l}\text { Std. Error of } \\
\text { the Estimate }\end{array}$ & $\begin{array}{l}\text { Durbin- } \\
\text { Watson }\end{array}$ \\
\hline 1 & $.710^{\mathrm{a}}$ & .504 & .498 & .71424 & 1.992 \\
\hline
\end{tabular}

Predictors: (Constant), Salesmanship Skill, Technical Skills, Marketing Skill, Interpersonal Skills, b. Dependent Variable: salesperson performance

Table 3 Coefficients

Standa

Unstandardiz rdized

ed Coeffi

Coefficients cients

Std.

\begin{tabular}{|c|c|c|c|c|}
\hline Model & B & Error & Beta & $t$ \\
\hline 1 (Constant) & .554 & .279 & & $\begin{array}{r}1.98 \\
5\end{array}$ \\
\hline $\begin{array}{l}\text { Interperso } \\
\text { nal Skills }\end{array}$ & .515 & .055 & .489 & $\begin{array}{r}9.39 \\
6\end{array}$ \\
\hline $\begin{array}{l}\text { Marketing } \\
\text { Skills }\end{array}$ & .147 & .062 & .118 & $\begin{array}{r}2.38 \\
6\end{array}$ \\
\hline $\begin{array}{l}\text { Salesmans } \\
\text { hip Skills }\end{array}$ & .184 & .052 & .181 & $\begin{array}{r}3.50 \\
9\end{array}$ \\
\hline
\end{tabular}

a. Dependent Variable: salesperson performance

\subsection{Hypothesis testing}

Hypothesis test statements are formulated for test the differences between variables and variables of this study (Sekaran, 2010). In statistics H0 states Null Hypothesis which could state there is no correlation between two variables on the other side Ha alternative hypothesis states there is a relationship existing between two variables (Sekeran, 2010). Sekeran (2010) study states $P$ value is 
the observed significant level. If $\mathrm{p}$ value higher than $0.5(\mathrm{p}>0.5) \mathrm{H} 0$ will be rejected and vice versa.

H1: There is a significant relationship between interpersonal skills and salesperson performance.

Regression analysis indicates significant positive relationship between interpersonal skills and salesperson performance at $95 \%$ significant level since $(\beta=0.515, \mathrm{P}=0.000)$. Correlation also supported this statement $(\mathrm{r}=$ $0.677, \mathrm{P}=0.000$ ). Hence, $\mathrm{H} 0$ is rejected since, $\mathrm{P}<0.05$. H1 Accepted

Churchill et al. (2000) stated interpersonal skills positively affected the sales performance. The present study suggested that the general insurance industry sales persons expect to have higher interpersonal skills to improve the sales performance. Higher interpersonal skilled sales person will retain their customer for a longer period this will reduce the customer churning rate.

H2: There is a significant relationship between salesmanship skills and salesperson performance

According to regression analysis illustrates that salesmanship skills has a significant impact on sales performance the positive beta reveals the positive impact on sales performance at $95 \%$ significant level since $(\beta=0.184$ and $P=0.000)$. The Correlation further supported above hypothesis $(\mathrm{r}=0.550, \mathrm{P}=0.000)$. Hence, $\mathrm{H} 0$ is rejected since, $\mathrm{P}<0.05$. $\mathrm{H} 2$ accepted

The empirical study supported that the positive relationship between salesmanship skills and sales performance Johlke, (2006) moreover the researcher emphasized to ensure the trainings sessions to presentation skills and adaptive behaviours to improve the salesmanship performances. The study also reaffirmed that the general insurance industry sales personals also have to have higher salesmanship skills.

H3: There is a significant relationship between technical skills and salesperson performance.

As indicated by regression analysis model for the beta value between technical skills and sales performance was not significant at $95 \%$ significant level. This explains technical skills has not a significant positive impact on sales performance. Moreover correlation emphasized the weak positive correlation between two variables ( $\mathrm{r}$ $=0.299, \mathrm{P}=0.000)$. Hence, $\mathrm{H} 0$ is accepted since, $\mathrm{P}>0.05 \mathrm{H} 3$ Rejected. Previous study also supported that have no significant relationship between the technical skill and sales person performance (Basir, Ahmad \& Kitchen, 2010).

Muthusamy and Fernando (2016) stated in Sri lankan general insurance industry sales persons have a technical Knowledge Gap and this sector sales personals not much concern on the technical knowledge when it comes to the practical scenario because the technical skills become obsolete time to time innovations, abnormal weather conditions, environmental changes in Sri Lanka but Schimit, Lee and Lilien (2014) states it is important to improve sales force in depth knowledge on product portfolio.

H4: There is a significant relationship 
between marketing skills and salesperson performance.

As indicated by regression analysis model for the beta value between marketing skills and sales performance was positive $(\beta=$ 0.147 and $\mathrm{P}=0.018$ ) at $95 \%$ significant level. This explains marketing skills has a significant positive impact on sales performance. Moreover correlation emphasized the positive correlation between two variables $(r=0.499, \mathrm{P}=0.000)$. Hence, $\mathrm{H} 0$ is rejected since, $\mathrm{P}<0.05$. H4Accepted

\section{Managerial Implication}

The general insurers have to recruit sales agents with high interpersonal skills, sales presentation skills and marketing skills. The insurers have to provide structured training programmes to newly recruit sales persons on the industry, customer nature, products design and development to improve the winwin situations. The regulators need to ensure appropriate educational level qualifications for the sales persons. The insurers company should safeguard the experienced sales personals to retain in the company because training a newly appointed salesperson cost more.

\section{Conclusion}

The study emphasized the urgency of the industry requirement for increase the sales to survive in the market. The customer relationship is most important to the general insurance industry. The nature of the business highly depends on the customer gut feeling. To regain the customer trust the sales persons support is essential to lift up the industry performance. Therefore, the general insurance industry needs highly skilled persons for utilize the sales targets and retain the customer. In Sri lankan context no studies have conducted research regarding this context. Hence, the study will be a most essential and initial step to explore the research regarding this discipline. The study shows that the salesperson must have high interpersonal skills, salesmanship skills and marketing skills to attract and retain the customers from the general insurance industry. Thus, the study will be a most essential and initial step to explore the research regarding this discipline.

\section{Reference}

Alberts, L. J. S. M., Peeters, I. R., Braekers, R., \& Meijer, C. (2006). Churn Prediction in the General Sciences, Maastricht University.

Basir, M. S., Ahmad, S. Z., \& Kitchen, P. J. (2010). The Relationship between sales skills and salesperson performance: an empirical study in the Malaysia Telecommunications Company.

Brown, S. P., \& Peterson, R. A. (1994).The effect of effort on sales performance and job satisfaction. The Journal of Marketing, 70-80.

Castleberry, S. B., \& Shepherd, C. D. (1993). Effective interpersonal listening and personal selling. Journal of Personal Selling \& Sales Management, 13(1), 3549.

Churchill, Gilbert, A., Neil, M., Ford, 
Steven, W., Hartley, Orville, C.,\& Walker, Jr. (1985). The Determinants of Salesperson Performance: A MetaAnalysis. Journal of Marketing Research, 22 (May),103-118.

Darmon, R. Y., Duclos-Gosselin, L., \& Rigaux-Bricmont, B. (2013). A Measure of Dynamic Market Performance.

Demirdjian, Z. S. (1984). A multidimensional approach to motivating salespeople. Industrial Marketing Management, 13(1), 25-32.

ErastusYamoah, E. (2013). Factors Affecting the Performance of Sales Personnel of Insurance Companies in Ghana. Kuwait Chapter of Arabian Journal of Business and Management Review, 2(12), 73-79.

Farhang, F., \&Hasely, M. (2013). How about the Low Performers?: A study on below average salesmen.

Güneş, E. D., Akşin, O. Z., Örmeci, E. L., \& Özden, S. H. (2010). Modeling customer reactions to sales attempts: if crossselling backfires. Journal of Service Research, 13(2), 168-183.

Holyoake, J., \& Weipers, W. (2002). Insurance:Insitute of Financial Services. London: IBT Global.

Insurance Board of Sri Lanka. (2015). Annual Report 2015. Retrieved 17.09.2016,from http://www.ibsl.gov.lk/

Johlke, M. C. (2006). Sales presentation skills and salesperson job performance. Journal of Business \& Industrial Marketing, 21(5), 311-319.

Jarrar, Y. F., \& Neely, A. (2002). Cross-selling in the financial sector: customer profitability is key. Journal of Targeting, Measurement and Analysis for Marketing, 10(3), 282-296.
Kamakura, W. A., Ramaswami, S. N., \&Srivastava, R. K. (1991).Applying latent trait analysis in the evaluation of prospects for cross-selling of financial services. International Journal of Research in Marketing, 8(4), 329-349.

Kamakura, W. A., Wedel, M., De Rosa, F., \& Mazzon, J. A. (2003). Cross-selling through database marketing: A mixed data factor analyzer for data augmentation and prediction. Interna tional Journal of Research in marketing, 20(1), 45-65.

Kavoosi, S., Sadeghian, S., \& Mahmudi, K. (2014). An Empirical Investigation of the Impact of Customer Orientation, adaptive selling behaviors, and job satisfaction on salespeople's perfor mance: The Moderating Role of Selling Experience. International Journal of Research in Management, 4(3), 74-88.

Krishnan, B. C., Netemeyer, R. G., \& Boles,

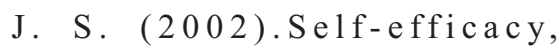
competitiveness, and effort as antece dents of salesperson performance. Journal of Personal Selling \& Sales Management, 22(4), 285-295.

Kazén, M., Kuhl, J., Boermans, S., \& Koole, S. L. (2013). Excelling at selling: The charming personality style predicts occupational activities, sales perfor mance, and persuasive competence. Psych Journal, 2(2), 86-100.

Li, S., Sun, B., \& Wilcox, R. T. (2005). Cross-selling sequentially ordered products: An application to consumer banking services. Journal of Marketing Research, 42(2), 233-239.

Muthusamy. V., \& Fernando, K.D.U.D. (2016), Key determinants of cross 
selling of dwelling house insurance policies for life insureds' in Sri Lanka, Juice 2016 International Research Conference, University of Jaffna Sri Lanka.

Nair, M., Vivek, S., \& Acharya, V. (2014). Sri Lanka 2013 Insurance Industry Report. India: Insure Risk Management \& Insurance Broking Services pvt.Ltd

Rahmnanjee, H.A. (2007). Understanding Insurance. Colombo: Vishvakekna.

Rapp, A., Agnihotri, R., \& Forbes, L. P. (2008). The sales force technologyperformance chain: The role of adaptive selling and effort. Journal of Personal Selling \& Sales Management, 28(4), 335-350.

Rentz, J. C., Shepherd, D., Armen, Tashchian, A., Dabholkar, P. A. \& Ladd, R. T. (2002). A measure of selling skill: Scale development and validation. The Journal of Personal Selling \& Sales Management, 22 (Winter), 13-21.

Rizal, M., Idrus, M. S., \& Djumahir, M. R. (2014). Effect of Compensation on Motivation, Organizational Commi tment and Employee Performance (Studies in Local Revenue Management in Kendari City). International Journal of Business and Management Invention, 3(2), 64-79.

Román, S., \& Iacobucci, D. (2010). Antecedents and consequences of adaptive selling confidence and behavior: a dyadic analysis of salespeople and their customers. Journal of the Academy of Marketing Science, 38(3), 363-382.
Salazar, M. T. (2010). Modelling cross-sales to promote customer retention in the financial services industry: the'whowhat-when framework'. Two case studies.

Schmitz, C., Lee, Y. C., \& Lilien, G. L. (2014). Cross-selling performance in complex selling contexts: an examin ation of supervisory-and compensationbased controls. Journal of Marketing, 78(3), 1-19.

Sekaran, U. (2010). Research Methods for Business: A Skill Building Approach (5th ed.) Wiley.

Terho, H., Kairisto-Mertanen, L., Bellenger, D., \& Johnston, W. J. (2013). Salesperson goal orientations and the selling performance relationship: The critical role of mediation and moderation. Journal of Business Market Management, 6(2), 70-90.

Thangakone,J. (2001). Insurance Industry and General Insurance In Sri Lanka. Colombo: The Sri Lanka Insurance Institute

Weeralingam, K., Illangasekera, P. (2011). Insurance Sector Update. Colombo: RAM Rating Lanka LTD.

Weitz, B. A., \& Bradford, K. D. (1999). Personal selling and sales management: A relationship marketing perspective. Journal of the academy of marketing science

YorMalhotra, N. K., \& Peterson, M. (2006).Basic Research Marketing: A Decision-Making Approach (2 $2^{\text {nd }}$ Ed.). New Jersey: Pearson Education, Inc.k. 